\title{
SUBSTRATE EFFECTS ON SURVIVAL, GROWTH AND DISPERSAL OF JUVENILE SEA SCALLOP, PLACOPECTEN MAGELLANICUS (GMELIN 1791)
}

\author{
MÉLANIE BOURGEOIS, ${ }^{1}$ JEAN-CLAUDE BRÊTHES ${ }^{1} *$ AND MADELEINE NADEAU ${ }^{\mathbf{2}}$ \\ ${ }^{1}$ Institut des Sciences de la Mer de Rimouski, Université du Québec à Rimouski, 310 Allée des \\ Ursulines, G5L 3A1, Québec, Canada; ${ }^{2}$ Ministère de l'Agriculture des Pêcheries et de l'Alimentation du \\ Québec, Direction de l'Innovation et des Technologies, 184 Principale, \\ Cap-aux-Meules, Québec, G4T 1C6
}

\begin{abstract}
In the scope of expanding seeding operations of juvenile scallops (Placopecten magellanicus) around Îles-de-laMadeleine (Quebec, Canada), this study assesses the influence of substrate on growth, survival, dispersal and predation rates in controlled experiments. Three substrates were tested: gravel, sand and sand with empty scallop shells (to investigate the feasibility of modifying the substrate as a management strategy). Dispersal rates were studied with a substrate choice experiment. Predation experiments with two major scallop predators, the rock crab Cancer irroratus and the sea star Asterias vulgaris, were carried out on different substrate types. No significant difference in growth was observed among substrates and no mortality was observed during the experiment. This suggests other factors, such as hydrodynamics, may be more important than substrate. The dispersal rate was significantly greater on sandy substrate, whereas gravel and sand-shells had similar results. Crab predation was lower on the more heterogeneous substrate (i.e., gravel) whereas, sea star predation was lower on sand. Modifying the natural sand substrate by adding scallop shells could improve seeding success because it diminishes dispersal and predation by crabs.
\end{abstract}

KEY WORDS: scallop, Placopecten magellanicus, seeding, mortality, growth, dispersal, substrate, predation, Cancer irroratus, Asterias vulgaris

\section{INTRODUCTION}

To restore the overexploited population of sea scallop Placopecten magellanicus (Gmelin 1791) around Îles-de-la-Madeleine (Quebec, Canada), an experimental restocking program was launched in 1993. After the pilot phase, commercial seedings started in 2000 with the intent to seed 35-50 million young scallops annually. However, because of the expected expansion of the program, the availability of substrate suitable for growth, survival and retention of seeded individuals is likely to become an issue. Around the islands, $70 \%$ of the substrate in the scallop habitat depth range $(9-55 \mathrm{~m})$ is sandy.

Substrate characteristics influence scallop survival and growth. Whereas adult sea scallops are found on various substrates, gravel and pebbles are the most suitable (Thouzeau et al. 1991a, Stokesbury 2002, Kostylev et al. 2003). Fine particles such as silt decrease survival rate (Yamamoto 1957), and sandy substrate may increase juvenile mortality (Stokesbury \& Himmelman 1996, Cliche et al. 1994). In natural conditions, fine inorganic material that is easily resuspended in the water column by currents or wave action is known to have a negative impact on growth in some scallop species (Gruffyd 1974, Bricelj \& Malouf 1984). Emerson et al. (1994) demonstrated that high concentrations of seston inhibit sea scallop growth. Nevertheless, substrate heterogeneity has a positive effect on scallop growth. Turbulence created by a heterogeneous bottom may cause local seston accumulations by slowing down the current (Pilditch et al. 1998). A decreasing current speed may improve scallop filtering efficiency, because scallop growth is inhibited in strong current conditions (Bricelj \& Shumway 1991, Wildish \& Saulnier 1993).

Substrate type is also an important factor for scallop dispersal, as demonstrated by several authors (Winter \& Hamilton 1985, Barbeau et al. 1996, Stokesbury \& Himmelman 1996, Arsenault et al. 2000). Young individuals are active swimmers (Manuel \& Dadswell 1991), but they also must attach themselves to the bot-

\footnotetext{
*Corresponding author. E-mail: jean-claude_brethes@uqar.qc.ca
}

tom with a byssus (Hatcher et al. 1996), which reduces dispersal and limits the displacement out of a suitable substrate (Caddy 1972). Therefore, hard substrates possess characteristics that limit juvenile scallop displacement (Caddy 1972, Thouzeau et al. 1991b, Parson et al. 1992, Hatcher et al. 1996). It has been observed that dispersal rates and swimming activities of Chlamys islandica and P. magellanicus are higher on sand (Stokesbury \& Himmelman 1996, Arsenault et al. 2000).

The major cause of scallop mortality on the bottom is known to be predation by rock crabs (Cancer irroratus, Say) and sea stars (Asterias vulgaris, Verrill) (Barbeau et al. 1994, Hatcher et al. 1996, Nadeau \& Cliche 1998). Seeded scallops may have a better chance of survival on heterogeneous substrates: they are less exposed to predators because they can hide in crevasses. Wright (2002) showed that scallops preferentially settled on heterogeneous substrates like pebbles when they were alone or in the presence of crabs. In addition, increasing particle sediment size tended to decrease the predation rate of sea stars on small scallops (11-15 $\mathrm{mm}$ ) but not crab predation (Wong \& Barbeau 2003).

The main goal of this study is to determine juvenile $P$. magellanicus survival, growth and dispersal on 3 different substrates (sand, gravel and sand with scallop shells) in laboratory experiments. In addition, the predation rate by rock crab (C. irroratus) and sea star (A. vulgaris) in relation to the substrate type was examined.

\section{MATERIAL AND METHODS}

Juvenile scallops came from the stock prepared for the 2002 commercial enhancement off Îles-de-la-Madeleine. They were kept in experimental tanks individually supplied with filtered circulating seawater at ambient salinity and temperature. The water passed trough a pool filter loaded with sand-blast sand size \# 0 and 1, diameter $0.4 \mathrm{~mm}$ to $2 \mathrm{~mm}$. The flow rate was adjusted to allow the water in the tanks to be renewed twice daily. Therefore, current velocity in tanks was very low. Temperature was monitored daily from $2002 / 05-2002 / 11$ and varied between $2.9^{\circ} \mathrm{C}$ and $23.2^{\circ} \mathrm{C}$. Total suspended particulate matter in the water circuit was measured 
weekly $\left(2.53 \pm 1.54 \mathrm{mg} \cdot \mathrm{L}^{-1}\right.$, mean $\left.\pm \mathrm{SE}, n=100\right)$. Light followed the natural photoperiod, with the intensity dimmed to simulate bottom luminosity.

\section{Survival and Growth}

Scallop growth and survival were studied on 3 substrate types: gravel (D50 [median particle size of the sample] $=8400 \mu \mathrm{m}$ ), sand $(\mathrm{D} 50=336.5 \mu \mathrm{m})$ and sand with complete scallops shells (superior and inferior valves; shell height $=113 \pm 2 \mathrm{~mm}$, mean \pm SE, $n=33$ ) covering about $25 \%$ of the tank bottom. Experiments lasted 88 days, from 2002/05/30-2002/08/26 and water temperature varied between $9.8^{\circ} \mathrm{C}$ and $23.2^{\circ} \mathrm{C}$. Four replicates of each treatment were distributed randomly in twelve 160-L tanks $(0.8 \mathrm{~m}$ length $\times 0.5 \mathrm{~m}$ width $\times 0.4 \mathrm{~m}$ height $)($ Fig. 1a,b). Each tank represented one trial. Scallops $(25.0 \pm 0.1 \mathrm{~mm}$ shell height, mean \pm SE, $n=177$ ) were tagged a few days before seeding with Hallprint plastic tags $(4 \mathrm{~mm} \times 9 \mathrm{~mm})$ fixed with Bostik cyanoacrylate adhesive glue. The plastic tags were also used to fix a monofilament nylon line on each scallop. In each tank, 15 scallops were tethered with a $12-\mathrm{cm}$ monofilament nylon line tied with a solid glued knot onto a galvanized clamp hidden $5 \mathrm{~cm}$ in the substrate. This system was designed to avoid scallop settlement along the tank walls. Live scallops were counted once a week.
Growth rate was calculated as the size increment between the beginning and the end of the experiment.

\section{Dispersal}

Dispersal was assessed with a substrate choice experiment (M. Fréchette, Maurice Lamontagne Institute, pers. comm.) in three 1,500-L tanks ( $2.4 \mathrm{~m}$ length $\times 1.2 \mathrm{~m}$ width $\times 0.6 \mathrm{~m}$ height $)$ (Fig. $1 \mathrm{c}, \mathrm{d})$. The tested substrate was laid in the middle of the tank, covering a surface of $1.20 \mathrm{~m} \times 0.60 \mathrm{~m}\left(0.70 \mathrm{~m}^{2}\right)$ and surrounded by the reference substrate around the perimeter of the tank $(0.70$ $\mathrm{m}^{2}$ ). In a preliminary experiment, conducted at the average temperature and with each substrate type, indicated random scallop displacements and no location preference was observed (pers. obs.). Three treatments were used: gravel as tested substrate with sand as reference, sand as tested substrate with gravel as reference and sand with $25 \%$ of the area covered with entire scallop shells (shell height $=110 \pm 3 \mathrm{~mm}$, mean $\pm \mathrm{SE}, n=21$ ) as tested substrate with gravel as reference. Thirty juvenile scallops $(25 \mathrm{~mm}$ shell height, $n=1075$ ) were seeded on the central zone from a basket maintained above the water surface. Each trial, carried out on the three treatments simultaneously, lasted $54 \mathrm{~h} ; 12$ replicates were done for each treatment. Scallops that stayed on the tested substrate were counted regularly (T0, T2, T4, T6, T8, T12, T24, a)

c)

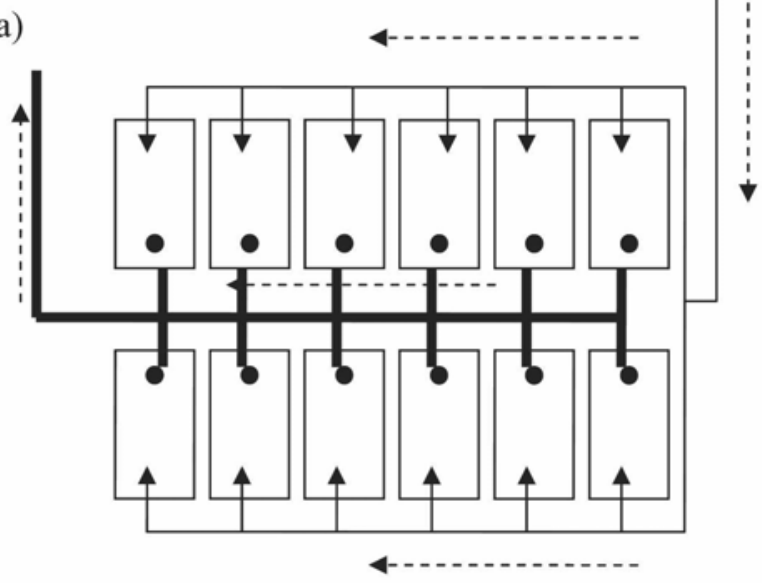

b)

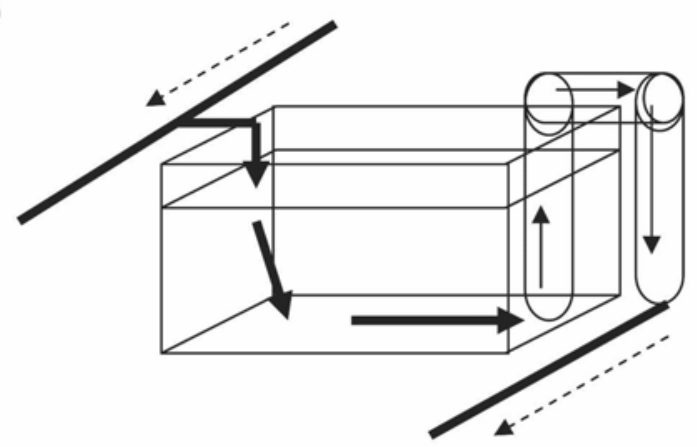

d)

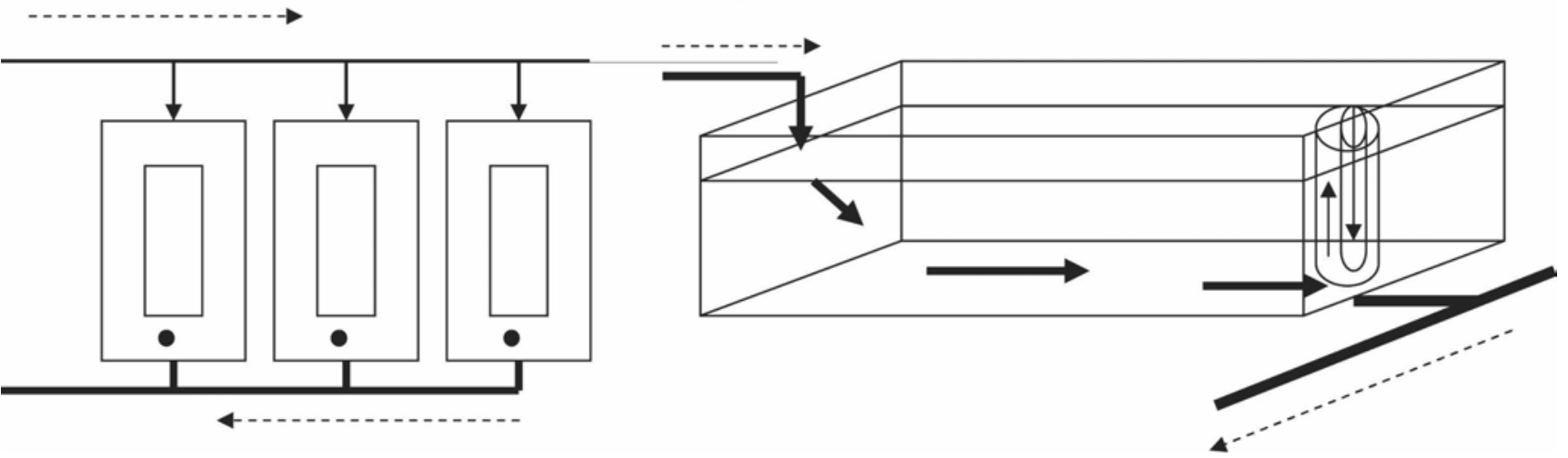

Figure 1. Set-up of tanks: (a) upper and (b) lateral views of the tanks system used for growth experiment, (c) upper and (d) lateral views of the tanks system used for dispersal and predation experiments. 
T36, T48, T54 h). The experiment took place between May 24, 2002 and July 8, 2002, and water temperature varied from $8.6^{\circ} \mathrm{C}$ and $19.5^{\circ} \mathrm{C}$. During the last seven replicates of the dispersal experiment, the position of the scallops (on the sand, or under or over shells) and the status (byssally attached or not) on the sand-shell substrate was noted.

\section{Predation}

An experiment was conducted from September 17, 2002 to September 26, 2002 (water temperature from $13.3^{\circ} \mathrm{C}$ to $17.5^{\circ} \mathrm{C}$ ) to evaluate predation on juvenile scallops by crabs and from October 15, 2002 to November 14,2002 (water temperature from $2.9^{\circ} \mathrm{C}$ to $10.2^{\circ} \mathrm{C}$ ) to evaluate predation by sea stars. Scallops used for these experiments were $28.0 \pm 0.1 \mathrm{~mm}$ shell height (mean $\pm \mathrm{SE}, n=720$ scallops). Three $1500-\mathrm{L}$ tanks $(2.4 \mathrm{~m}$ length $\times 1.2 \mathrm{~m}$ width $\times$ $0.6 \mathrm{~m}$ height) (Fig. 1c,d) with a single substrate (gravel, sand or sand with scallop shells) were used. Tank size was expected to avoid limitations in escape responses because of tank's walls. Two predator species were considered: the rock crab, Cancer irroratus (92 $\pm 1 \mathrm{~mm}$ carapace width, mean $\pm \mathrm{SE}, n=41)$ and the sea star, Asterias vulgaris $(74 \pm 2 \mathrm{~mm}$ radius, mean $\pm \mathrm{SE}, n=87)$. Both predators were collected off Îles-de-la-Madeleine by a Digby-type scallop drag and acclimated to laboratory conditions for 1 month before the experiment. Predators were kept in perforated baskets ( 4 per basket) in a tank with filtered circulating seawater and fed twice a week with two mussels (Mytilus edulis) or two clams (Mya arenaria) per predator. Only male crabs were used to avoid sexrelated biases. Predators were starved $48 \mathrm{~h}$ prior to the beginning of the experiment. During the crab experiments, two crabs were introduced into the tank $24 \mathrm{~h}$ after juvenile scallops had been added ( $n=30$ per tank). Survivors were counted every $4 \mathrm{~h}$ until the end of the 12-h trial. For sea stars, four predators were used in a 96-h trial and their positions were noted at each observation time. Scallop survivors in each substrate treatment were counted every $24 \mathrm{~h}$. Predator sizes and time periods were based on the results of preliminary experiments carried on for each predator (Nadeau et Cliche 1998). Four replicates of each substrate treatment were done for the crab and sea star experiments. During the trial, it was difficult to determine whether scallops were hidden or consumed by predators. Therefore, to avoid possible bias, scallops were removed at the end of each trial to count the number of survivors. The position and status (alive or dead) of scallops present on the sand-shell substrate were noted at each observation time.

We based our analysis of scallop reactions on the classification of their positions at the end of the trial: (1) in contact with a hard part of the substrate (shells or attached to a neighboring scallop); (2) in contact with shells only (attached or not; under or over a shell); (3) attached to hard part of substrate and (4) located under a shell but not necessarily attached to it (refuge use). Here we use "in contact" to describe scallops touching a hard substrate, whether they are attached or not. The first two categories identified the frequency at which scallops were using a hard surface in the presence of a predator and if shells were "preferred" or not. The third category determined the proportion of scallops in contact with a hard substrate but also byssally attached to it; this category defined a subset of scallops in the category one. The fourth category was used to define the proportion of scallop shells used as refuges; this category defined a subset of the category two. The proportion of hidden live scallops also served to compare the use of refuges in the presence of crabs and sea stars.

\section{Statistical Analysis}

Statistical tests were done with Systat 10.2 software with a probability level $(\alpha)$ of 0.05 . No statistical test was necessary for the analysis of survival data without predation because there were no mortalities. Growth data were analyzed using a 2-factor nested ANOVA with substrate ( 3 levels) as the fixed factor and tank (12 levels) as the random factor nested into the substrate. Normality was assessed using a 1-way Kolmogorov-Smirnov test and homogeneity of variances by a Levene test. The dispersal data were analyzed using 1-way ANOVAs with substrate (3 levels) as the fixed factor (1 per hour). The number of scallops present on the tested substrate (located in the middle of the tanks) at each observation time was used as the dependant variable. Normality was assessed using a 1-way Kolmogorov-Smirnov test and homogeneity of variances by a Cochran test (Critical C: 0.8709). One-way ANOVAs were used for crab and sea star predation data at the end of the experiment, with substrate as a factor (3 levels). This was done separately for each predator species. Normality was assessed by a 1-way Kolmogorov-Smirnov test and homogeneity of variances by a Levene test. A posthoc Tukey test was applied on the results to test specific differences when ANOVAs showed significant effects.

\section{RESULTS}

No mortality was observed during the survival and growth experiments without predators. Growth did not differ significantly between substrates (ANOVA: $\mathrm{F}_{(2,168)}=1.62, P=0.852$ ). Growth rate was $1.5 \pm 0.1 \times 10^{-1} \mathrm{~mm} \cdot \mathrm{d}^{-1}$ (mean $\pm \mathrm{SE}$ ) on sand-shells, $1.5 \pm 0.1 \times 10^{-1} \mathrm{~mm} \cdot \mathrm{d}^{-1}$ on gravel and $1.5 \pm 0.1 \times$ $10^{-1} \mathrm{~mm} \cdot \mathrm{d}^{-1}$ on sand (Fig. 2). Tank had a significant effect on growth (ANOVA: $\mathrm{F}_{(9,168)}=10.07, P<0.001$ ). Growth differences were noted in relation to tank position in the water circuit (i.e., growth rate was lower in the middle than at the water inflow and outflow). This indicates that the system used may have created a bias as the slowest growth was observed in the middle section. All tanks were fed individually but the flow rate in tanks of the middle section was more variable and often difficult to adjust. However, that bias does not affect the general results.

Substrate had a significant effect on scallop dispersal (ANOVA: $\left.\mathrm{F}_{(2,33)}=3.59-18.78, P<0.05\right)$. Weak dispersal was observed on gravel substrate (Fig. 3). The dispersal of scallops was

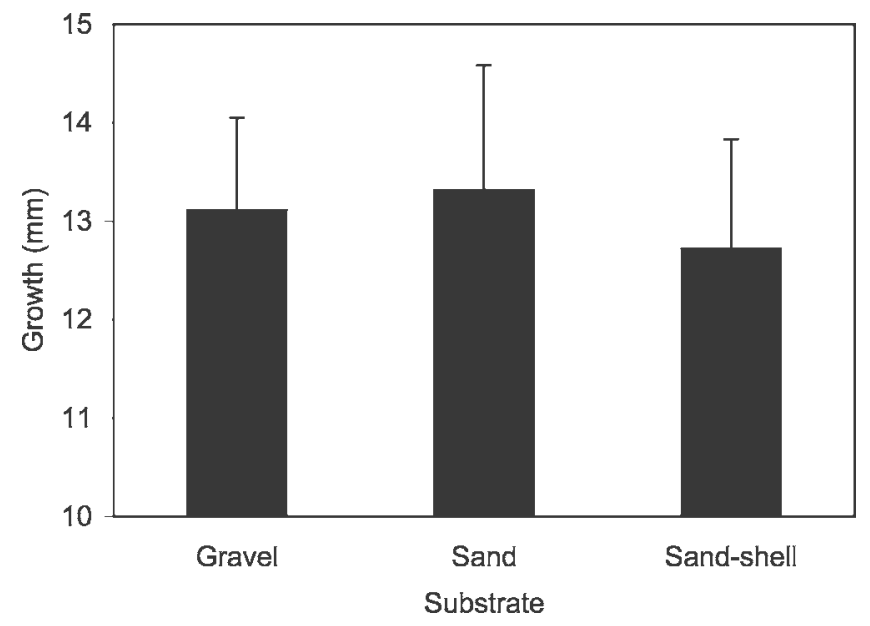

Figure 2. Mean growth ( $\mathrm{mm} \pm \operatorname{standard}$ error, $n=4)$ of juvenile sea scallops on gravel, sand and sand-shell over 12 wk (88 days). 


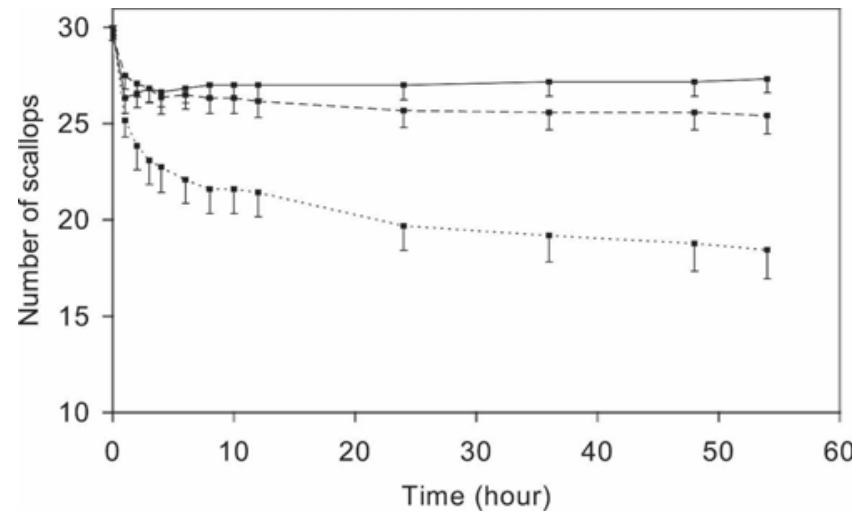

Figure 3. Mean hourly abundance (half standard error, $n=12$ ) of juvenile sea scallops remaining on each tested substrate (gravel: plain line; sand-shell: dashed line; sand: dotted line).

slightly higher on the sand-shell substrate than on gravel, but the difference was not statistically significant (posthoc Tukey test: $P=0.32$ ). Dispersal increased during the first $6 \mathrm{~h}$ on those two substrates and stabilized afterward, with only 10 and $17 \%$ of individuals moving off of the gravel and sand-shell substrates, respectively. Dispersal on sand was significantly higher than on the other two substrates. This difference was already significant by the second hour of the experiment and remained so until the end $\left(\mathrm{F}_{(2,33)}=3.59-18.78, P<0.05\right)$. Within the first $6 \mathrm{~h}, 27 \%$ of the seeded scallops moved away from sand, increasing to $40 \%$ by the end for the trials. In all treatments, some individuals moved away from the reference substrate and went back to the tested substrate. Fourteen scallops returned to gravel, four to sand-shells and only two to sand.

On sand-shell substrate, $76.8 \pm 3.9 \%$ (mean \pm SE) of juvenile scallops were found in contact with hard parts of the substrate and the others were unattached. Of these scallops in contact with hard part of the substrate, $71.6 \pm 9.3 \%$ were found in contact with empty shells $(70.0 \pm 12.9 \%$ located under shells $)$ and the others with a neighbor scallop. A proportion of $40.1 \pm 8.66 \%$ of individuals in contact with hard parts substrate were byssally attached to it.

After $12 \mathrm{~h}$, crab predation was highest on sand (mean $\pm \mathrm{SE}$, $n=7: 9.3 \pm 2.6$ live scallops, i.e., $69 \%$ of scallops eaten) and lowest on gravel $(22.8 \pm 1.5$ live scallops, $24 \%$ of scallops eaten $)$ (Fig. 4). Survival on sand-shell was similar to that on gravel, with $20.8 \pm 4.4$ live scallops ( $30 \%$ of scallops eaten). However, the

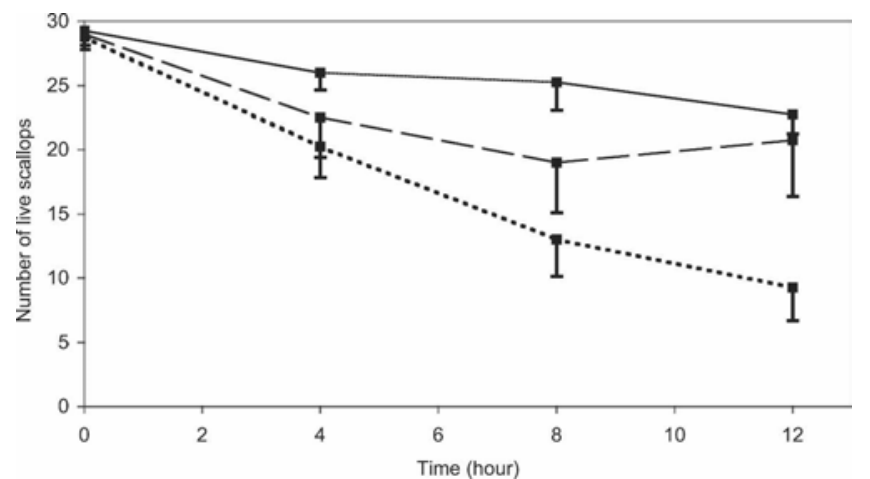

Figure 4. Mean number of scallops surviving crab predation at each observation time (half standard error, $n=7$ ) on the tested substrates (gravel: plain line; sand-shell: dashed line; sand: dotted line). difference between the three treatments was not significant (ANOVA: $\mathrm{F}_{(2,9)}=3.24, P=0.087$ ). On sand-shell substrate, $20 \%$ to $40 \%$ of the scallops were hidden under shells. Crabs are fast-moving predators and required a short time for prey handling, leaving only shell fragments. When crabs were not moving, they were immobile on gravel (often near a corner of the tank) or buried in sand. Crabs often moved shells and seemed to have difficulty discriminating prey from nonprey items. Some scallops were so well hidden that counting was biased, causing an increase in the count of live scallops at the very end of the experiment. Thus, the final number is the most accurate because all scallops were removed and counted.

Contrary to crabs, sea star predation (Fig. 5) after $96 \mathrm{~h}$ was lowest on sand (mean \pm SE: $22.8 \pm 1.9$ live scallops, $n=7$ ) and highest on gravel and sand-shells $(17.8 \pm 2.3$ and $17.0 \pm 1.1$ live scallops, respectively); however, the rates were not significantly different (ANOVA: $\mathrm{F}_{(2,9)}=1.63, P=0.248$ ). Gravel and sandshell substrates showed a similar pattern: $41 \%$ and $43 \%$ of scallops were consumed, respectively, on these substrates after $96 \mathrm{~h}$ compared with an average of $24 \%$ on sand. The level of predation increased in the following order: sand $<$ gravel $\approx$ sand-shells. Sea stars are slow-moving predators, and the time required for prey handling is longer than for crabs; handling time per prey could last $24 \mathrm{~h}$. Sea stars spent most of their time on the walls of the tanks. When they were not on the tank walls, they were found more often on the gravel substrate (average 1.6 sea stars per trial) and sandshells (average 1.3 sea stars per trial) than on sand (average 0.8 sea star per trial).

The juveniles' use of scallop shells was different between the rock crab and sea star experiments. The proportion and number of live scallops observed under shells increased with time in the presence of crabs (Fig. 6a), whereas it was relatively stable in the presence of sea stars (Fig. 6b). On average, $29.4 \pm 2.8 \%$ (mean \pm SE, $n=4$ ) of the live scallops were hidden under shells in experiments with crabs, significantly higher than the average of $10.4 \pm 1.5 \%$ with sea stars (Mann-Whitney $U$-test, $P<0.0001$ ).

\section{DISCUSSION}

Contrary to previous studies, substrate type in our experiment did not have any effect on juvenile scallop survival because no mortality (without predators) occurred. These differences can be attributed to experimental conditions, such as the low density and low current conditions in our tanks. Higher densities or faster

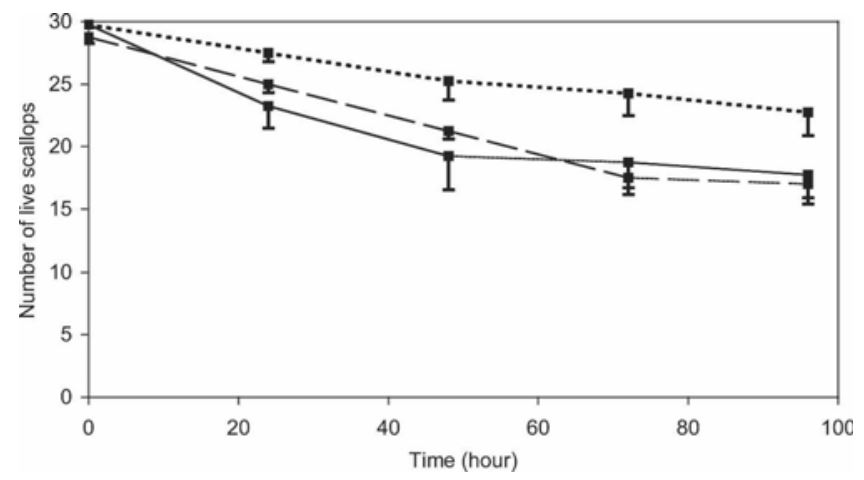

Figure 5. Mean number of scallops surviving sea star predation at each observation time (half standard error, $n=7$ ) on the tested substrates (gravel: plain line, sand-shell: dashed line; sand: dotted line). 
a)

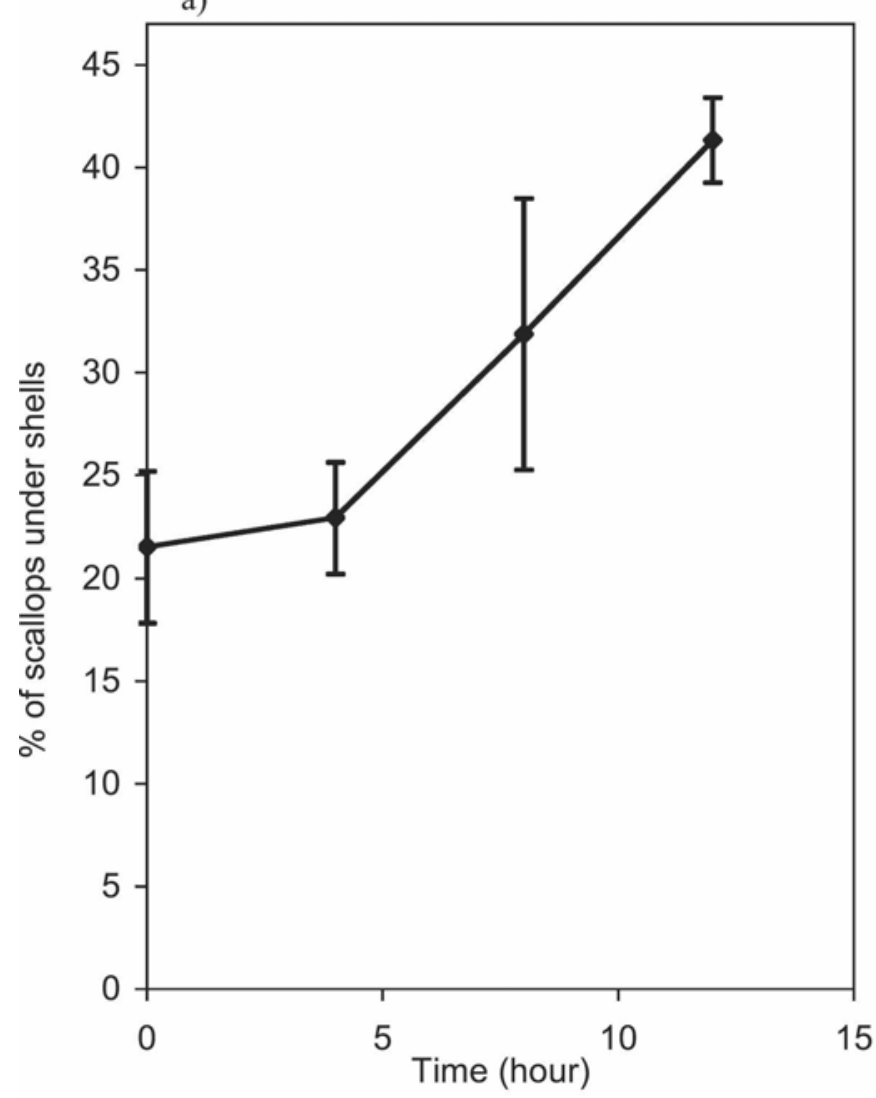

b)

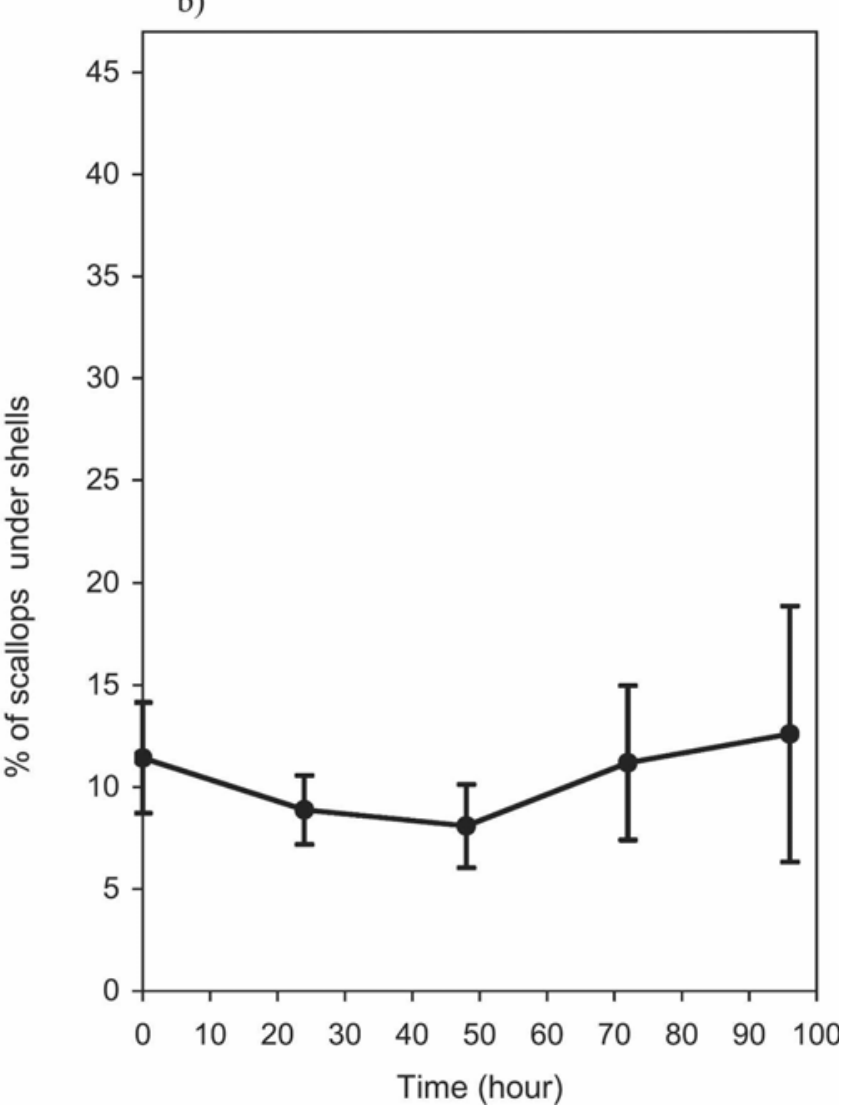

Figure 6. Percentage of live scallops found under shells (mean $\pm \mathrm{SE}, n=4)$ in the presence of (a) rock crabs and (b) sea stars.

water flow can favor resuspension of fine particles and increase mortality rates, as may be the case in the natural environment.

In our study, substrate type did not have any effect on growth rate. Scallop growth is known to be directly correlated with organic matter input (Kleinman et al. 1996, Pilditch \& Grant 1999) and inversely correlated with inorganic matter (Cranford 1995). On heterogeneous substrates, like gravel or sand with shells, the topography may induce local accumulations of organic matter while reducing current velocity (Pilditch et al. 1998). Those accumulations and resulting increase in food availability would enhance scallop growth. The optimal current velocity for scallop filtering activity is $10 \mathrm{~cm} \cdot \mathrm{s}^{-1}$ (Wildish \& Saulnier 1993), whereas feeding is totally inhibited in strong currents (Wildish \& Saulnier 1993). In our experiment, reduced flow and low organic matter input may have tempered the direct effect of the substrate on growth, suggesting that hydrodynamic conditions prevailing on the bottom may be more important than substrate alone.

As expected, dispersal was significantly different among substrate types, with the highest dispersal rate noted on sand. Adding scallop shells onto the sand induced a dispersal pattern similar to the one observed on gravel. Other studies found that dispersal was related to substrate type. In field experiments, Stokesbury and Himmelman (1995) observed less scallop dispersal when seeding occurred on gravely and rocky bottoms than on sandy bottoms. The preferential use of heterogeneous substrate is related to juvenile scallop behavior (Hatcher et al. 1996): the juveniles in our study needed a suitable substrate for attachment. When scallops were seeded on sand, they swam until reaching a place to fix themselves, such as gravel or shells. Scallops on gravel spent less time swimming and tended to remain on the same site. The addition of scallop shells to the sand increased the potential attachment sites, thus reducing scallop dispersal and making this substrate comparable to gravel. On the sand-shell substrate, $40 \%$ of the scallops were attached together in groups of two or three or attached to shells. Fréchette (IML-MPO, pers. comm.) has observed some groups of two or three young scallops attached together on sand. This behavior was also noted on sand in this study, but it was unusual on the gravel substrate. However, the study by Stokesbury and Himmelman (1996) indicates that juvenile sea scallops disperse randomly. In this study, the high level of movements from sand to gravel cannot be attributed to a pure random dispersal. Present results should be completed with other studies to further document scallop's behavior on the various substrate arrangement.

Predation rates were not statistically significant between substrates. Temperature could have been a factor (Barbeau \& Scheibling 1994b), but temperature changes in each predator experiment were not sufficiently high to account for those results. Because the number of replicates was low (four), individual behavior of predator could have masked any effect and, thus, a higher number of replicates (which was not feasible here because of technical constraints) could have shown more evident results. Even if not statistically demonstrated, trends, however are clear enough to be interpreted. Crab predation decreased with an increase in substrate heterogeneity, with a lower mortality being observed on gravel. On the sand-shell substrate in the presence of predators, as much as $40 \%$ of the live scallops were located under shells. A larger number of scallops used refuges on the sand-shell substrate in the crab experiment and this number increased with time. On sand, only 
$31 \%$ of scallops were still alive at the end of the experiment. There was less predation by crabs on the sand-shell substrate than sand. Crab predation is known to be mostly affected by the encounter rate (predator and prey density) because they are fast-moving and have a low prey handling time (Barbeau et al. 1994, Nadeau \& Cliche 1998). Sponaugle and Lawton (1990) observed a higher consumption rate of Mercenaria mercenaria on sand than on sand-shell substrate by the crabs Ovalipes ocellatus (Herbst) and Callinectes sapidus (Rathbun) caused by a higher foraging time on the sand-shell substrate. During our experiment, crabs had difficulty discriminating prey items and nonprey items, as was also observed by Wong and Barbeau (2003). Adding shells to the bottom may increase crab foraging time, and scallop survival may be greater because of the decreasing encounter rate. Crabs are visual and chemodetecting predators and can move fast. The scallop escape response in our crab experiment was passive, scallops closed their valve, as has been observed by Barbeau and Scheibling (1994a and b). The presence of shells diminishes the encounter rate with scallops, and one can expect the same effect on crab predation in natural conditions.

In the presence of sea stars, scallop survival was greater on the sand substrate, unlike the experiment with crabs. Experiments on the sand-shell substrate showed survival values intermediate to survival on gravel and sand. When sea stars were not foraging, they moved along the walls of the tanks. Their foraging time on the gravel and sand-shell was twice as high as on sand, perhaps explaining the high scallop survival on sand. Sea stars are slow moving predators and can easily detect chemical signals of organic substances (Zafiriou 1972, Barbeau et al. 1994, Rochette et al. 1994, Gaymer et al. 2002). This explains why shells did not provide an adequate protection against sea stars, which were able to detect scallops in refuges. In addition, scallops have an efficient escape response from slow moving predators like sea stars, and juveniles have better swimming capacities to escape than adults (Barbeau et al. 1994). In fact, scallops did not use refuges as intensively as with crabs. Sea star predation rate is affected by a decrease, a weakness or a distortion of chemical signals (Rochette et al. 1994) and by the probability of capture on encounter (Barbeau et al. 1994). In natural habitats, shells can induce a distortion in the chemical signal in strong current condition and decrease encounter probability. The low current conditions in our experi- mental tanks may explain why shells seemed to be less effective against sea stars than against crabs.

In our laboratory experiment, sand appeared to be a suitable substrate for scallop survival and growth that was similar to gravel and sand-shell substrate but less suitable for dispersal and against crab predation. Seeded scallops are more vulnerable to predation and need short-term protection against predators when they are released on the bottom. Scallop shells may increase the suitable area for byssus attachment and may provide some refuge from predators. The positive effect of adding shells to the bottom has already been shown. Guay (2003) found that the richness and the density of most common invertebrates increased on sand by adding scallop shells. That author also observed that 2 predators, Leptasterias polaris (Müller and Troschel) and Hyas araneus (Linnaeus), were attracted to sand and gravel enriched by shells, but that that attraction was more important on gravel. In field experiments, Pacheco and Stotz (2003) showed that settlement and survival of Argopecten purpuratus (Lamarck) was improved by adding crushed and empty shells to the bottom compared with natural bottoms (sand and mud). Thouzeau et al. (1991a) noted that the sand-shell (medium sand with quahog, scallop and surf-clam shells) portion of Georges Bank has a lower density of decapods and sea stars than coarse sediments like gravel and pebbles. The effect of substrate on survival, growth and dispersal of juvenile sea scallops was tested in the present controlled experiments. However, that effect may be different in the natural environment, where hydrodynamic processes and many other biotic and abiotic factors may influence the conditions. Attempts were made to transpose the experimental results to field experiments around Îles-de-laMadeleine (Bourgeois 2004). Because technical biases occurred, those experiments were unable to provide useful data. Considering the promising results of this study, further research is required to better assess the feasibility of substrate modification to improve scallop seeding success.

\section{ACKNOWLEDGMENTS}

The authors thank the Company "Petoncle 2000," which provided the young scallops and raising facilities and Dr M. Barbeau (University of New-Brunswick) for her helpful comments. This project was funded by a special grant from the Quebec Department of Agriculture, Fisheries and Food (MAPAQ).

\section{LITTERATURE CITED}

Arsenault, D. J., M. C. Giasson \& J. H. Himmelman. 2000. Field examination of dispersion patterns of juvenile Iceland scallops (Chlamys Islandica) in the northern Gulf of St.-Lawrence. J. Mar. Biol. Assoc. U.K. 80:501-508.

Barbeau, M. A., B. G. Hatcher, R. E. Scheibling, A. W. Hennigar, L. H. Taylor \& A. C. Risk. 1996. Dynamics of juvenile sea scallop (Placopecten magellanicus) and their predators in bottom seeding trials in Lunenburg Bay, Nova Scotia. Can. J. Fish. Aquat. Sci. 53:2494-2512.

Barbeau, M. A. \& R. E. Scheibling. 1994a. Behavioral mechanisms of prey size selection by sea stars (Asteris vulgaris, Verril) and crabs (Cancer irroratus, Say) preying on juvenile sea scallops (Placopecten magellanicus, Gmelin). J. Exp. Mar. Biol. Ecol. 180:103-136.

Barbeau, M. A. \& R. E. Scheibling. 1994b. Temperature effect of juvenile sea scallops [Placopecten magellanicus (Gmelin)] by sea star (Asterias vulgaris, Verrill) and crabs (Cancer irroratus, Say). J. Exp. Mar. Biol. Ecol. 182:27-47.

Barbeau, M. A., R. E. Scheibling, B. G. Hatcher, L. H. Taylor \& A. W. Hennigar. 1994. Survival analysis of tethered juvenile sea scallops
Placopecten magallenicus in field experiments: effect of predators, scallop size and density, site and season. Mar. Ecol. Prog. Ser. 115: 243-256.

Bourgeois, M. 2004. Effet de la survie, la croissance et la dispersion du Pétoncle géant juvénile Placopecten magellanicus (Gmelin 1791). M. Sc. thesis, Université du Québec à Rimouski. (Québec, Canada). $125 \mathrm{pp}$.

Bricelj, V. M. \& S. E. Shumway. 1991. Physiology: energy acquisition and utilization. In: S.E. Shumway editor. Scallops: biology, ecology and aquaculture. New York: Elsevier. pp. 305-346.

Bricelj, V. M. \& R. E. Malouf. 1984. Influence of algal and suspended sediment concentrations on the feeding physiology of the hard clam Mercenaria mercenaria. Mar. Biol. 84:155-165.

Caddy, J. F. 1972. Progressive loss of byssus attachment with size in the sea scallop, Placopecten magellanicus (Gmelin). J. Exp. Mar. Biol. Ecol. 9:179-190.

Cliche, G., M. Giguère \& S. Vigneau. 1994. Dispersal and mortality of sea 
scallops, Placopecten magellanicus (Gmelin, 1791), seeded on the sea bottom off Îles-de-la-Madeleine. J. Shellfish Res. 13-2:565-570.

Cranford, P. J. 1995. Relationship between food quantity and quality and absorption efficiency in sea scallop Placopecten magellanicus (Gmelin). J. Exp. Mar. Biol. Ecol. 189:123-142.

Emerson, C. W., J. Grant, A. Mallet \& C. Carver. 1994. Growth and survival of sea scallops Placopecten magellanicus: effects of culture depth. Mar. Ecol. Prog. Ser. 108:119-132.

Gaymer, C. F., J. H. Himmelman \& L. E. Johnson. 2002. Effect of intraand interspecific interactions on the feeding behavior of two subtidal sea stars. Mar. Ecol. Prog. Ser. 232:146-162.

Gruffyd, L. D. 1974. The influence of certain environmental factors on the maximum length of the scallop, Pecten maximus L. J. Cons. Explor. Mer. 35(3):300-302.

Guay, M. 2003. L'addition de coquilles de pétoncles (Chlamys islandica) sur différents types de fonds marins: une alternative pour favoriser le recrutement des espèces commerciales? M.Sc. Thesis, Université Laval, Québec (Canada). 49 pp.

Hatcher, B. G., R. E. Scheibling, M. A. Barbeau, A. W. Hennigar, L. H. Taylor \& A. J. Windust. 1996. Dispersion and mortality of a population of sea scallop (Placopecten magellanicus) seeded in a tidal channel. Can. J. Fish. Aquat. Sci. 53:38-54.

Kleinman, S., B. G. Hatcher, R. E. Scheibling, L. H. Taylor \& A. W. Hennigar. 1996. Shell and tissue growth of juvenile sea scallops (Placopecten magellanicus) in suspended and bottom culture in Lunenburg Bay, Nova Scotia. Aquaculture 142:75-97.

Kostylev, V. E., R. C. Courtney, G. Robert \& B. J. Todd. 2003. Stock evaluation of giant scallop (Placopecten magellanicus) using highresolution acoustics for sea bed mapping. Fish. Res. 60:479-492.

Manuel, J. L. \& M. J. Dadswell. 1991. Swimming behaviour of juvenile giant scallop, Placopecten magellanicus, in relation to size and temperature. Can. J. Zool. 69:2250-2254.

Nadeau, M. \& G. Cliche. 1998. Predation of juvenile sea scallops (Placopecten magellanicus) by crabs (Cancer irroratus and Hyas sp.) and starfish (Asterias vulgaris, Leptasterias polaris and Crossaster papossus). J. Shellfish Res. 17-4:905-910.

Pacheco, A. \& W. Stotz. 2003. Effects of substrate availability and characteristics on recruitment and survival of Argopecten purpuratus (Lamarck 1819). In: 14th International Pectinid Workshop, April $23-$ 29, St. Petersburg, Florida. Book of abstracts. 202 pp.

Parson, G. J., C. R. Warren-Perry \& M. J. Dadswell. 1992. Movements of juvenile sea scallop Placopecten magellanicus (Gmelin, 1791) in Passamaquody Bay, New Brunswick. J. Shellfish Res. 11-2:295-297.

Pilditch, C. A. \& J. Grant. 1999. Effect of temperature fluctuations and food supply on the growth and metabolism of juvenile sea scallop (Placopecten magellanicus). Mar. Biol. 134:235-248.
Pilditch, C. A., C. W. Emerson \& J. Grant. 1998. Effect of scallop shells and sediment grain size on phytoplankton flux to the bed. Cont. Shellfish Res. 17-15:1869-1885.

Rochette, R., J.-F. Hamel \& J. H. Himmelman. 1994. Foraging strategy of the asteroid Leptasterias polaris: role of prey odors, current and feeding status. Mar. Ecol. Prog. Ser. 106:93-100.

Sponaugle, S. \& P. Lawton. 1990. Portunid crab predation on juvenile hard clams: effect of substrate type and prey density. Mar. Ecol. Prog. Ser. 67:43-53.

Stokesbury, K. D. E. 2002. Estimation of sea scallop abundance in closed areas of Georges Bank, USA. Am. Fish. Soc. 131:1081-1092.

Stokesbury, K. D. E. \& J. H. Himmelman. 1996. Experimental examination of the movement of the giant scallop, Placopecten magellanicus. Mar. Biol. 124:651-660.

Stokesbury, K. D. E. \& J. H. Himmelman. 1995. Biological and physical variables associated with the aggregations of the giant scallop Placopecten magellanicus. Can. J. Fish. Aquat. Sci. 52:743-753.

Thouzeau, G., G. Robert \& R. Ugarte. 1991a. Faunal assemblage of benthic mega invertebrates inhabiting sea scallop grounds from eastern Georges Bank, in relation to environmental factors. Mar. Ecol. Prog. Ser. 74:61-82.

Thouzeau, G., G. Robert \& S. J. Smith. 1991b. Spatial variability in distribution and growth of juvenile and adult sea scallops Placopecten magellanicus on eastern Georges Bank (Northwest Atlantic). Mar. Ecol. Prog. Ser. 74:205-218.

Wildish, D. J. \& A. M. Saulnier. 1993. Hydrodynamic control of filtration in Placopecten magellanicus. J. Exp. Mar. Biol. Ecol. 174-1:65-82.

Winter, M. A. \& P. V. Hamilton. 1985. Factors influencing swimming in bay scallops, Argopecten irradians (Lamark, 1819). J. Exp. Mar. Biol. Ecol. 88:227-242.

Wong, M. C. \& M. A. Barbeau. 2003. Effects of substrate on interactions between juvenile sea scallops (Placopecten magellanicus Gmelin) and predatory sea stars (Asterias vulgaris Verrill) and rock crabs (Cancer irroratus Say). J. Exp. Mar. Biol. Ecol. 287:155-178.

Wright, L. D. 2002. Substrate preferences of juvenile sea scallop (Placopecten magellanicus), sea stars (Asterias vulgaris), and rock crabs (Cancer irroratus). A thesis presented to the Department of Biology, University of New Brunswick, in partial fulfillment of the requirements of Bachelor of Science with honours in biology. April 2002. 47 pp.

Yamamoto, G. 1957. Tolerance of scallop spat to suspended silt, low oxygen tension, high and low salinities and sudden temperature changes. Science Report of Tohoku University, 4th series. Biology 22:149-156 (English translation).

Zafiriou, O. 1972. Response of Asterias vulgaris to chemical stimuli. Mar. Biol. 17:100-107. 